\title{
On the Waterfront (1954): Film and the Dilemmas of American Liberalism in the McCarthy Era
}

By

Charles J. Maland

University of Bergen/University of Tennessee

What is the relationship between feature films and the culture in which they are made? Are movies like mirrors that reflect social reality? Are they more like archaic road maps that mislead viewers by depicting old paths of outmoded values? Are they instead like windows that present within the boundaries of the movie screen small but accurate social "slices of life"? Or are they perhaps like lamps that illuminate viewers about the workings of the society?

Surely none of these metaphors - of films as mirrors, maps,. windows, or lamps - can adequately describe in general terms. the complex ways in which films relate to the society in which they were made. While each metaphor contains a grain of truth when applied to some films, the particular film one chooses to study largely determines how one answers the question of how films relate to their society. In short, different films present different problems and suggest different answers.

In this essay I would like to apply this question of film's relation to society to the well-known film On the Waterfront (Columbia, 1954). Through the film's narrative, I shall argue, the director, Elia Kazan, is justifying his testimony before the House UnAmerican Activities Committee in the early 1950s. To generalize further, On the Waterfront is a social document that can help us understand the dilemmas of American liberalism during the McCarthy era, thus making the film one which relates closely to society through the way it dramatizes a central ideological conflict of American culture in the 1950s. 
No Hollywood filmmaker has more clearly reflected shifts in the

;host-war American mind than Kazan.

Jim Kitses ${ }^{1}$

The dominant climate of opinion in America society shifted dramatically between the worst years of the Great Depression and the first decade after World War Two. The breakdown of the American economy alter the Stock Market Crash of 1929, which by $1932 \mathrm{had}$ led to an unemployment rate of around $30 \%$, understandably pushed many artists and intellectuals to a greater interest in political issues and greater desire forsocial reform. Liberals drifted leftward from their political positions of the 1920s. Yet the political spectrum began to shift back toward the right in the late 1930s, due largely to the widespread acceptance of Franklin Roosevelt's New Deal legislation, and to an increasing awareness of the threat of German fascism. World War Two both strengthened the American economy and helped to create an ideological consensus of values in the country. Americans spent much time and energy defining a set of positive values, sometimes called "Americanism," which provided an alternative to the ideology of Fascism and a rationale for fighting in World War Two. After the war, this consensus of values hardened as many Americans began to perceive the Soviet Union as a new menace to the ideology of Americanism, a totalitarian threat from the left rather than from the right. Between 1947 and 1954 America went through a particularly intolerant period: social criticism of American society, particularly from a leftist perspective, became almost taboo as many artists and intellectuals were pressured to prove their loyalty to "Americanism." Those artists and intellectuals who in the 1930s had been members of or were sympathetic to the Communist Party of America (CPA) and who by the late 1940s considered themselves liberals - one of whom was Elia Kazan - found themselves in an ideological quandary. ${ }^{2}$

Elia Kazan was born in Turkey in 1909, spending his early childhood in Istanbul and Berlin. When Kazan was four, his father moved the family to New York, where he established a rugimporting business. The business prospered and Kazan himself was well educated, attending a Montessori school and entering 
Williams College, an elite eastern liberal arts school, after graduating from high school. At Williams between 1926 and 1930, the immigrant Kazan felt like an outsider, recalling to an interviewer that "I had this antagonism to privilege, to good looks, to Americans, to WASPs (White Anglo Saxon Protestants)." 3

During the early 1930s, in the depths of the depression, Kazan lived in New York City, and studied as an apprentice at the Group Theater, an organization known for its interest in producing socially conscious, politically left-wing work like that of Clifford Odets. Influenced by both the aesthetic and the political climate of the Group Theater, and animated by an idealistic concern about the economic problems wrought by the depression, Kazan joined the Communist Party in 1934 and remained a member for nineteen months.

After he broke with the Communist Party in 1936, Kazan became what might be labeled a reform-minded liberal, sympathetic to problems of the working classes, interested in art which depicted social problems. Though never very successful as an actor, Kazan began to direct plays as early as the middle 1930s. After the breakup of the Group Theater, Kazan went to Hollywood, where by 1944 he had directed his first film, A Tree Grows in Brooklyn. By the early 1950s he was in great demand as both a theater and film director. Not only had he directed the New York stage premieres of Tennessee Williams' A Streetcar Named Desire (1347) and Arthur Miller's Death \& a Salesman (1949) - arguably the two most important American plays in the decade after World War II - but he had also become widely known as a director of liberal social problem films treating such issues as anti-Semitism (Gentleman's Agreement, 1948) and racism (Pinky, 1959). Just as his career was at its peak, however, he began to have difficulties with the House Committee on Un-American Activities (HUAG).

It should be noted here that after World War Two, HUAC investigated the centers of the American film industry on two separate occasions. En the first, during 1947, the Committee focused on alleged subversive content in the Hollywood films themselves. This investigation culinated in the infamous Hollywood Ten trials, in which ten Hollywood film employees, among them Dalton Trumbo, John Howard Lawson, Alvah Bessie, and Ring Lardner, Jr., were cited for Contempt of Congress and given prison sentences of a year for refusing to testify about their past political activities and associations. Nevertheless, the stated purpose 
of this investigation was to examine whether Hollywood films conained subversive material.

In 1951, after all the judicial appeals of the Ten had been exiausted, HUAC again began to investigate Hollywood for Comnunist influence, this time focusing on subversive people rather han subversive content in the films. If anything, the Gold War $\mathrm{lad}$ intensified in the intervening years, and the national paranoia ibout internal security had become even more pronounced. A lumber of events contributed to that increasing worry. In foreign uffairs between 1949 and 1952 the Communists gained political ontrol of China, the Soviet Union announced the successful deonation of an atondc bomb, and the Korean War had broken iut. Within the United States fear of Communist subversion had ed to the passage of the McCarren Act over 'Truman's veto, the ipholding of the 1940 Smith Act by the Supreme Court, and the xecution of Julius and Ethel Rosenberg as spies. The cultural tmosphere in the early 1950s was difficult to breathe for those rho had been Communist paty members and ardent anti-Fascists I the 1930s.

Between 1947 and 1951 American liberalism itself was going arough a crisis, largely in trying to define an attitude toward re Communist Party. Since American liberals had often cooperated rith socialists and communists against fascism before and during Vorld War Two, they had difficulty deciding what position to ake vis-à-vis communism and civil liberties after the Soviet Union egan to be widely perceived as a threat in 1946 and 1947. Liberals suld defend the right of communists to express their views and ven be willing to cooperate with communists in politically left auses, but this was the exception. From the foundation of the rongly anti-Communist liberal Americans for Democratic Acon in 1947, more and more American liberals began to move sward the middle of the political spectrum. One of the founders the ADA, New Deal liberal Arthur Schlesinger, labeled this beralism "the Vital Center" in his influential book of 1949. To $\mathrm{Lm}$, as to a growing number of liberals in the late $1940 \mathrm{~s}$, Ameran liberalism was the only realistic alternative to repressive ctatorships on the Communist left and the Fascist right. Though " course not all liberals drifted into this centrist liberalism, many d. The American Civil Liberties Union became quite hesitant defend actively the civil rights of communists from the 1940s 1, and the liberal American Committee of Cultural Freedom, 
of which Kazan was a member, had a strong anti-Communist tinge when it was revived in 1949. According to its first chairman, Sidney Hook, one of the goals of the congress was "to expose Stalinism and Stalinist liberals wherever you found them." Thus a wedge was being driven into American liberalism in the late 1940s and early 1950s over the issue of Communism.4

During this difficult period for American liberals, Kazan was asked to testify before an executive session of HUAC on January 14, 1952.5 There Kazan discussed his membership in the Communist Party in the 1930s but refused to name names of people whom he knew to be members of the Communist Party during those times. This refusal to name names was significant, for, since the testimony of actor Larry Parks in April, 1952, it had become apparent that such a refusal would lead film industry executives to blacklist the defendent, barring him from working in movies, television or the theater. A historian of HUAC has written that "the heads of the motion picture industry took the Congressmen's concentration on names rather than on films as a sign of grace, and bowed joyfully to it." As a result these studio heads, who had been lacing a steady decline in movie attendance since 1946 and couldn't afford to alienate the government, promised to blacklist those who refused to name names. Given the fact that even the Hollywood Guilds were refusing publicly to support those who were testifying in 1951 and 1952, it was clear that defendants from the entertainment industries were on their own. Though certain people subpoenaed refused to testify against friends and associates - Lillian Heliman and Arthur Miller were two naming names began to be a common occurrence in this second wave of HUAC investigations. ${ }^{7}$

Between January and April of 1952, Kazan changed his mind and wrote the committee telling them that he would like to testify again. He did, on April 10, 1952, this time naming names. His cooperative testimony was divided into three sections (Bentley, 482-95). The first describes Kazan's nineteen-month membership in the CPA in the 1930s, naming sixteen people he knew or was quite certain were members of the CPA, including playwright Glifford Qdets - who later was brought before HUAC to answer Kazan's allegations. In the second section of the testimony Mazan denies having been active after 1937 in any of the organizations listed by the government as subversive. Almost abjectly, he assures the committee that he did nothing "subversive" in the intervening 
years like sign the Stockholm peace pledge, attend the Waldorf Peace Conference, or vote for Henry Wallace in 1948 (each of these were also condemned by the "Vital Center"). The final section lists the plays and films Razan directed from 2938 on, accompanied by Kazan's often forced comments about how patriotic each work was. A typical example is Kazan's commentary on A Tree Grows in Brooklyn: "There is pain in the story, but there is health. It is a typically American story and could only happen here, and a glorification of America not in material terms but in spiritual ones" (Bentlcy, 494). In concluding, Kazan comments: "Firsthand experience of dictatorship and thought control left me with an abiding hatred of these. It left me with an abiding hatred of Communist philosophy and methods" (Bentley, 494). Overall, the testimony is one of a man who wishes to please the committee completely and to portray himself as a hundred-per-cent American. The extent to which he was successful is indicated by Rep. Frances Walter's words of thanks after Razan finished his second testimony:

Mr. Kazan, we appreciate your cooperation with our Committee. It is only through the assistance of people such as. you that we have been able to make that progress that has. been made in bringing the attention of the American people to the machinations of this Communist conspiracy for world. domination. (Bentley, 495)

Kazan's concern about his reputation after informing is revealed by another document: a two-column, full-page advertisement - paid 'or, written, and signed by Kazan - appearing in theNew York Times .wo days after this testimony. It aims to clarify Kazan's reasons 'or naming names. The first sentences read: "In the past weeks.. ntolerable rumors about my political position have been circuating in New York and Hollywood. I want to make my stand slear."' Kazan goes on to argue that the "hysteria" about comnunist activities in America can only be cooled if the American seople have "bard and exact facts." After brieily outlining his zarcer in the CPA, Kazan describes CP tactics in a way, ironically snough, that could have equally well described those of HUAC. 'The Communists automatically violated the dayly practices of lemocracy to which I was accustomed. They attempted to control hought and to suppress personal opinion. They tried to dictate sersonal conduct." Saying that he had come to believe that 
"liberals must speak out," Kazan argues that secrecy serves both the communists and "those who are interested in silencing liberal voices." Finally hinting at what was surely one of his central motives - his career - Kazan writes: "The employment of a lot of good liberals is threatened because they have allowed themselves to become associated with or silenced by the Communists." The last quarter of the statement, borrowed from his testimony, stresses Mazan's hatred of Communism and his belief in the Will of Rights. In the final sentence he vows to "continue to make the same kinds of pictures and to direct the same kind of plays" - those which "represent my convictions" - as he had in the past.

Taken together, the testimony and the advertisement present Kazan as a liberal who had moved into the anti-Communist "Vital Center." In his few comments about his testimony since that time, he has reinforced that view. During the early 1950 's, he recalled to an interviewer: "I was bewildered. I was antiStalinist and anti-McCarthy at the same time. It was difficult to reconcile the two."9 While he did not reconcile these positions,. Kazan did achieve a purpose in his testimony and advertisement: he continued to work in the film industry and in the theater. While both are fascinating documents revealing liberal dilemmas in the early 1950s, even more fascinating is a film which surely does represent Kazan's convictions, more perhaps than even he knew at this time: On the Waterfront.

\section{III}

Terry Malloy felt as I did,

Elia Kazan ${ }^{10}$

After his second testimony to HUAC, Kazan and screenwriter Budd Xchulberg set out to rewrite a script originally based on a series of articles about waterfront corruption written for the New York Sun by Malcolm Johnson. ${ }^{11}$ After completing the screenplay, Kazan found financial backing from an independent producer, Sam Spiegel, and proceeded to cast the film, largely with actorsfrom the Actor's Studio in New York City. The film was shot primarily on location in Hoboken, New Jersey, between November 17, 1953, and January 26, 1954. After editing and the addition of Leonard Bernstein's score, the film was released by Columbia in July 1954 to generally good reviews and - given the fact that the film was a "social 
problem" film - a successful public response (the film grossed 4.2 million dollars in the U.S. alone). The film's greatest success, however, was within the Hollywood community itself: in the Academy Awards ceremony for 1954 films, On the Waterfront reaped eight Oscars, for best film, best actor (Marlon Brando as Terry Malloy), best supporting actress (Eva Marie-Saint as Edie Doyle), best director, best screenplay, best cinematography, art director, and editing. In addition, three of the five actors nominated for best supporting actor that year were from On the Waterfront: Karl Malden (as Father Barry), Rod Steiger (as Terry's older brother, Charley), and Lee J. Cobb (as the corrupt union boss, Johnny Friendly) ${ }^{12}$ All in all, the film strongly appealed to many Americans in 1954.

Very briefly, the story is about a young longshoreman, Terry Malloy, and his ambivalent relationship to the corrupt leadership of a dock workers' union, personified by its president, Johnny Friendly, and Terry's own brother, Charley. At the opening of the film, Terry unwittingly plays a partin the death of a friend, Joey Doyle, at the hands of the union leadership, who are afraid that Joey will become a Bey witness in an impending Waterfront Grime Gommission investigation of the union. Though the film does portray some realistic details of corrupt union methods and presents tensions between the leadership and some of the rank-and-file membership, Terry's dilemma gradually becomes the center of the film. Torn between acceptance of corruption and an easy, lucrative union job on the one hand, and - influenced by Joey's sister, Edie, and the crusading priest, Father Barry - rejecting the union leadership and testifying to the commission about Joey's death on the other, Terry finally testifies. Though his conscience is salved, he finds himself such a social pariah because of his testimony that he goes back to the waterfront to confront Johnny Friendly directly. After a brutal hand-to-hand struggle, Friendly is subdued, and the bloodied Terry struggles to walk along the dock toward the warehouse, leading the other rank-and-file union members back to work.

Just how does this film relate to American society? At the outset of this essay, I suggested that the film dramatizes several ideological dilemmas felt by many American liberals in the early 1950 s, particularly those liberals who had been sympathetic to the CPA in the 1930s. 'In particular, director Elia Kazan uses On the Waterfront as a way to answer three pressing questions 
confronting many American liberals during the McCarthy Era, particularly those liberals whose political and social views had been shaped during the Depression. In ascending order of importance, these questions can be framed like this:

I. How do I, as a liberal who believes that art should treat significant social topics from a progressive point of view, respond in an era where such controversy can lead me into trouble?

II. How do I, as a liberal, retain my commitments to the working classes and labor unions, in a time hostile to unions?

III. How do I, as a liberal, respond to the attempts of the government to limit my freedom of thought and association through loyalty oaths and investigations?

The way Kazan answered each of these questions tells us a great deal about the fate of American liberalism in the McCarthy Era.

The first question relates to the aesthetics of many American liberals who lived through the Great Depression. During this period of social unrest and suffering, many artists and intellectuals came to believe that good art must concern itself with the pressing social problems of the day and that the artist should be committed to and should express a "progressive" point of view. In the 1930s and early 1940s this article of aesthetic faith was reflected in works as diverse as Ben Shahn's paintings; "proletarian fiction" in its various forms; John Dos Passos' U.S.A. trilogy; Chaplin's Modern Times and The Great Dictator; Clifford Odet's Waiting For Lefty and many other Group Theater productions; documentary films like Pare Lorentz's The River and The Plow that Broke the Plains; the novel and film versions of Grapes \& Wrath; and even Hollywood topical films like $I$ am a Fugitive From $a$ Chain Gang. The committed liberal in the $1930 \mathrm{~s}$, particularly if he was a producer of culture in one of its various forms, was encouraged to take his art seriously and to reflect his commitments in his work. ${ }^{13}$

Kazan surely shared this view. His aesthetic position was shaped in the atmosphere of the early 1930s and the milieu of the Group Theater. Nearly all of his important work as director of films and plays after that reflected his interest in "committed" or topical art. And in On the Waterfront he remained true to his aesthetic principles. As already noted, an early version of the script was based on Malcolm Johnson's investigative reports on waterfront 
corruption in 1949. And when Kazan and Schulberg set about to rewrite the script after Kazan's 1952 testimony, they also drew on the public report of the New York State Crime Commission's investigation of waterfront crime: to no one's surprise, this report revealed a number of rampant illegal activities, ranging from extortion practiced on dock workers in exchange for guaranteed work, dishonest bookkeeping procedures and pension set-ups by union officials, and illegal strikes used to squeeze higher rates from shippers. ${ }^{14}$ Though, as we shall see, Kazan's point of view $\mathrm{n}$ the film is less than "progressive," in the 1930s sense of the term, he did fulfill the liberal commitment to topical art of signifcant social problems in making $O$ n the Waterfront.

Kazan's second dilemma related to the commitment of American iberals in the 1930s to the plight of the common man and consequently to labor unions as one solution to the inequitable distribuion of wealth and power under American capitalism. Liberals who attained their political consciousness in the 1930s generally ooked upon the rapid growth of unionism in the U.S., thanks n part to the passage of the Wagner Act in 1935, as an important tnd positive step in helping working-class Americans attain some :ense of security and equity in American society otherwise domnated by big business. Unions grew both in numbers and in Jower in the $1930 \mathrm{~s}$, but in the late $1940 \mathrm{~s}$, the climate of opinion n America shifted. In 1947 the Congress passed the Taft-Hartley Act, limiting the power of Pabor unions in several ways, while he national concern about loyalty and internal security led to an ittempt to ferret out Communist influence in labor unions.

How did Kazan respond in On the Waterfront to these changed ircumstances? Though the question cannot be answered simply, t seems evident that Kazan seemed to yield at least partially o the temper of the times. Instead of supporting the union wholeleartedly, as a liberal in the 1930s would likely have done, Kaan's treatment of the union is ambivalent, in this case reflecting he culture's stress on corruption in unions in the 194.0s and early 950s.

While it would be unfair to call On the Waterfront an anti-union ilm, the film's picture of unions rests in a grey area of ambiguity. In the one hand, Johnny Friendly and his subordinate union ifficials represent almost pure corruption. Though the film tries o soften this image of Johnny Friendly by giving him a speech bout how rough he had it as a bid, thus providing viewers with 
.a detail for understanding his actions, on the whole Friendly hardly lives up to his name. He not only supervises a series of illegal activities resembling those which the N.Y. Crime Commission revealed in 1952, but he also orders the deaths of three men in the film: Joey Doyle and K.O. Dugan, for threatening to inform, and Terry's own brother Charlie, for failing to control Terry.

On the other hand, On the Waterfroni presents a relatively sympathetic picture of the rank-and-file union members, as opposed to their corrupt leaders. Clearly these members are presented as victimized, as in the scene where the dock workers, after a union official tosses a handful of job markers on the ground, scramble on their hands and knees to grab the markers which will give them the right to work that day. In addition, the portrayals of K.O. Dugan and Edie's father deepen the sympathetic portrayal of the rank-and-file. Though Dugan may steal an occasional bottle of Irish whisky from the goods he helps to unload, his thefts are petty compared to the union's practices. Both he and Edie's father understand how they are victimized by the union, yet are strongly influenced by the dock workers' code of remaining " $D$ and $D$ " (deaf and dumb) about the sources of their victimization. Edie's father is too old and perhaps too beaten down to violate that code, but Dugan, believing that a good union could result if the officials were ousted, gradually decides that that possibility makes testifying worth the risk. His courage costs him his life, but his martyrdom inspires Terry to take up is cloak, both literally and figuratively (Terry eventually gets the jacket that Dugan had inherited from Joey Doyle). Overall, Kazan suggests that while the union leadership is certainly corrupt, the union members are hard-working, decent, and often courageous people who deserve much better than they are getting. Though Lindsay Anderson has forcefully argued in a famous review of the film that the rank-and-file as a mass in the film's final scene "are shown as incapable either of self-government or mutual aid," that view distorts the film's overall picture of unionism. ${ }^{15}$ It would thus be most accurate to say that Kazan resolved this second liberal dilemma by one step back and one step sideways, The step backwards is in the negative portrayal of the union leadership, while the step sideways comes in the film's sympathy for the victimized rank-and-file membership, the latter reflecting a good 1930s "progressive" attitude toward workers. 
The final ideological dilemma of liberalism in the McCarthy era treated in the film - and the one closest to the film's thematic center - relates to the question of bow American liberals reponded to loyalty tests and government investigations. This dilemma is worked out through the central conflict of the film: Terry Malloy's internal conflict about whether or not to testify against Johnny Friendly to the Waterfront Crime Commission. What I would like to argue in some detail is that Terry Malloy is a fictional embodiment of Kazan's own dilemma about his HUAG testimonies two years earlier and that On the Waterfront is on one level an elaborate allegory, Kazan's portrayal of the anguish he felt about testifying and a strong, if questionable, justification of his ultimate decision to inform.

If one knew nothing of Kazan's HUAC testimony, this allegorical level would be either obscured or altogether absent. But it becomes clear when one knows of Kazan's experience. In the allegory, Terry Malloy represents Kazan and his dilemma. The Waterfront Crime Commission is the House Un-American Committee patiently coaxing Terry/Kazan and others to provide information that will discredit forces of evil and restore "true Americanism." The Crime Commission is reinforced by the "good citizens" in the film: Father Barry and Edie, representing respectively the moral influence of religion and pure American womanhood. Finally, Johnny Friendly and his cohorts stand for - in what Peter Biskind aptly called the "submerged analogy" of the film - the Communist Party. ${ }^{16}$ Both of these groups - in Kazan's version of the story - represent an evil force which threatens individual freedom and violates principles of morality. In showing Terry's attempt to choose between the Grime Commission and Friendly, the allegory dramatizes and justifies Kazan's testimony. A closer look at the film itself can show us how the allegory functions. Clearly Terry Malloy is Kazan's fictional embodiment. Like Kazan, Terry must decide whether or not to testify against friends. Like Kazan, he ultimately chooses to do so. After the testimony Terry, like Kazan, is stunned by the response of friends: they shun him like the plague. Finally, Terry and Kazan both are extremely sensitive that their actions be considered morally corect: in an interview Kazan himself retrospectively touched on all these parallels. After his testimony, he told Michel Ciment, Many of my best friends... would pass me on the street and not say anything, not even nod to me ... 
Terry Malloy felt as I did. He felt ashamed and proud of himself at the same time. He wavered between the two, and he also felt hurt by the fact that people - his own friends were rejecting him. He also felt that it was a necessary act. He felt like a fool, but proud of himself because he found out that he was better than the other people around him. (Ciment, 86, 110)

Surely both Kazan and Terry felt ambivalence about their testimonies, yet unlike Kazan's situation, Terry's becomes an unambiguous moral necessity in the film, designed allegorically to present Kazan's testimony in the best possible light.

This leads us to the narrative and the question which dominates it: should Terry testify or not? The film is filled with references to the informer and various American nicknames for him: "stool pigeon," "pigeon," "cheese-eater," "cheesie," "canary," and "rat." In an early sequence, after two investigators have asked Terry to testify about Joey Doyle's death, Terry comments to another longshoreman: "How do you like those mugs, takin' me for a pigeon?" As the allegorial lines of the film are clearly drawn between true Americanism and citizenship on the one hand and false Americanism and corruption on the other, the only character who doesn't fall neatly into one of the two camps is Terry, the man on a tightrope.

, In deciding whether he should tell what he knows about Joey Doyle's death, Terry is counseled several time throughout the film. Terry's brother Charley and Father Barry provide the two main perspectives. When Terry is reluctant to follow Charley's orders to spy on the meeting at Father Barrey's church, Charley admonishes him: "Stooling is ratting on your friends, the people you're with." For Charley, the situation is solely one of loyalty to friends and trust in one's family. The informer is a Judas, selling friends for thirty pieces of silver. This temporarily satisfies Terry, though the tables are turned when Terry decides, after being influenced by Father Barry, Edie, and the Crime Commission investigators, that Johnny and his cohorts are not his friends.

In fact, Father Barry provides Terry with the alternative view of ratting in the film's next sequence: the church meeting where Terry does "spy" for Friendly. Closing his plea to the longshoremen, Father Barry stresses that someone must provide evidence about Joey Doyle's death. When Dugan tells Father Barry that 
dock workers have learned by the hard knocks of experience to be silent about corruption on the docks, he echoes the position Kazan seems to have held before testifying. ${ }^{17}$ But Father Barry answers Dugan's comment by presenting his position about informing: "What's ratting to them is telling the truth for you." For Father Barry informing is a positive step, a way to find the truth.

Thus, the issue is clearly presented by the sixth sequence (of twenty-three, by my count) of the film: what is ratting? Is it betraying the loyalty of friends or is it the action of a moral, responsible citizen? As the narrative develops from here, however, Kazan stacks the deck to such an extent that it leaves no doubt in our minds what decision Terry must make. While Father Barry and Edie place subtle moral pressure on Terry, Friendly becomes even more vicious in his threats and actions. From the beginning Terry knows about Joey Doyle's death, but then Friendly arranges for the murders of Dugan and, finally, of Terry's own brother. Charley's death makes Terry's decision for him: Terry testifies thereafter and in the final sequence tells Friendly: "I $I$ been rattin' on myself all these years, and I didn't know it. I'm glad what I done." Within the frame of the allegory, Kazan forcefully justifies his testimony.

But in this allegorical justification, Kazan simplifies and obscures the issues of his own testimony. Johnny Friendly's murders are hardly parallel to Communist Party membership in New York City in the mid-1930s. Likewise, the genial words of Crime Commission investigators in the film contrast starkly to the badgering tone of HUAC investigators to those who refused to cooperate with the committee. Finally, Terry Malloy has direct evidence that could help solve murders; Kazan knew a few people who had joined the Cornmunist Party in the 1930s, in the midst of the Depression. The death of Charley is the single most important event that makes the film's analogy a false one: as one observer has suggested, the film might have conveyed the anguish and complexities felt by the would-be informer if Charley had lived. By informing in that case, Terry would risk sending his brother to prison or perhaps even to his death. ${ }^{18}$

But Kazan simplified, making Terry's decision a simple moral issue: by informing Terry could help clean up the union and get personal revenge against Johnny Friendly for his brother's death. In contrast, it seems clear that Kazan's decision to testify was based as much on pragmatic as on moral grounds, for it saved 
him his own job and position of status and cultural power in Hollywood while placing others, those he named, in the same dilemma he encountered after receiving his subpoena from HAUG. But that is surely not the way Kazan wished himself to be perceived by others. The narrative of On the Waterfront shows how an American liberal Kazan attempted to maintain his self-esteem and justify his actions in an era hostile to his politics.

Kazan and his collaborators also used film style to intensify our sympathy for Terry's dilemma and to support his decision, thus strengthening the allegorical intentions. Though it is impossible to give a full reading of how Kazan used film style to build this sympathy for Terry, we can give a few examples. In terms of the visual style of the film, at least two devices stand out. The first is the tendency of Kazan and cameraman Boris Kaufman to "imprison" Terry in the frame by objects surrounding him. This most often happens on rooftop scenes, where the wire cages for the pigeons repeatedly seem to enclose and isolate Terry. But it also occurs when wooden planks surround him in the scene where Charley assigns him to spy, and in two other scenes where an iron fence behind him looks like a row of prison bars. Besides using these objects to imprison Terry, the filmmakers also often shoot him in closeups. This is not surprising, given the fact that the film centers on Terry's dilemma, but it is nonetheless important. Closeups intensify the dramatic impact of the image; in this case, they create greater audience identification with Terry and his emotional perspective.

Besides visual methods, the film uses the sound track and its three aspects - dialogue, sound effects, and music - to draw us closer to Terry. Marlon Brando's memorable delivery of Terry's lines ("I coulda been a contender, Charley, I coulda been somebody") shows us how the intonation, rhythm, and stress of the dialogue - as well as its content - can help the viewer empathize with Terry's anguished desire for self-esteem and to do the right thing. Sound effects are used most forcefully when a ship's whistle drowns out Terry's attempt to explain himself to Edie after telling her that he was involved in Joey's murder: through the sound, Kazan underlines Terry's frustration. Finally, two of the themes in Leonard Bernstein's score function similarly: the "Murder Theme" and the "Edie/Love Theme." The first is a harsh theme associated with Friendly and his gang. The second is much gentler and plays in several scenes where Terry and Edie are together. 
Taken together, the two themes subtly reinforce audience distaste for Friendly and identification with Terry and Edie.

Thus it is clear that Kazan uses both the narrative and the iilm style to draw his audience closer to Terry and to make Terry's decision to testify a justifiable, even morally necessary, act. The ideological significance of Kazan's allegory is thus quite clear: after suggesting that the decision to testify against friends caused a great deal of inner turmoil and anguish, Kazan chooses to present informing not simply as justifiable in certain circumstances, but as a positively courageous and heroic act of morality. Responding to this third ideological dilemma of American liberals in the McCarthy Era, Kazan answers with the rhetoric of selfjustification.

\section{IV \\ It [my testimony] was part of a thing that has to be under- stood in terms of that time.}

Elia Kazan ${ }^{19}$

We began the essay asking how feature films relate to the society they in which are made. In the case of On the Waterfront we've argued that one important way the two relate is ideological: the narrative of the film presents a "solution" to or working out of several ideological dilemmas felt by the filmmakers, particularly Elia Kazan, as he confronted a society hostile to the values he had formed nearly two decades earlier in quite different historical circumstances. We might properly close by connecting Kazan and On the Waterfront to a broader cultural circumstances in the early 1950s.

The character of American liberalism shifted significantly in the first decade after World War Two in its characteristic attitudes toward both domestic and foreign policy. Labeling this new liberalism "the Ideology of Liberal Consensus," Geoffrey Hodgson has argued that this new view rested on two basic assumptions. ${ }^{20}$ The first was that the American social and economic system, bolstered by New Deal welfare state legislation, had become essentially sound and just, and that whatever problems remained could be solved within the system by experts and managers. The second assumption related to foreign affairs: that the only serious 
threat to this basically admirable American society was the threat of Communism, which had to be countered by American military power around the world. According to Hodgson, this ideology dominated American political discourse from the late 1940s until the Civil Rights Movement and the Vietnam War challenged its basic assumptions in the 1960s.

Kazan and On the Waterfront reflect this basic shift in American liberalism. Kazan's liberalism had been formed in the 1930s, when liberals were sure about the domestic weaknesses in American society and worked actively to reformit. By the time of his testimony and On the Waterfront, however, Kazan's basic orientation had changed: pressures to prove one's loyalty had made Kazan much more positive toward basic American institutions and values: though he claimed in his second HUAC testimony to value deeply "free speech, a free press, the rights of labor, racial equality, and, above all, individual rights," he nonetheless felt it his "obligation as a citizen" to cooperate with HUAC (Bentley 494, 485). Significantly, this was the same government investigating committee that five years before - in the Hollywood Ten trials - he had actively opposed. In the same way Terry Malloy overcomes an early skepticism toward the Waterfront Crime Commission, finally cooperating fully with their investigations by testifying against Johnny Friendly. Though On the Waterfront is not so naively optimistic as to suggest Terry has single-handedly destroyed waterfront corruption - the shot af the unnamed wealthy and powerful man who cuts off all ties to Friendly after seeing Terry's testimony on TV proves this - it does without qualification endorse Terry's decision to cooperate with government officials in the name of "Americanism."

Kazan's liberalism was also formed in a very different international situation. The international threat to America in the mid and late 1930s was from the Fascist right. During the late 1930s and the war years liberals characteristically cooperated with the socialist and communist left in anti-fascist causes and indeed defined most of their values in contrast to fascism. However, when the Truman containment policy was articulated in 1947, Americans had begun to shift their antipathies from fascism to communism. Here again Kazan's shifts reflect those larger shifts of liberalism - his testimony not only stresses his "abiding hatred of Communist philosophy and methods," but it also proudly proclaims that his most recent film, Viva Zapata (1951), was "an 
nti-Communist picture." 21 We have already discussed the allegorcal anti-Communism of On the Waterfront, where a submerged nalogy equates Johnny Friendly's corruption with Communist illainy.

On an even broader level, American liberalism in the 1940s nd 1950s was shifting from a conflict view of American society, rhich stressed the differences in wealth and power among groups a America, to a consensus view of American society, which stressed n essential unity and harmony in American society. In the atellectual world, this shift was manifested by the emergence of ae consensus school of American history; the dominance of Talcott 'arsons' structural functionalism; the characteristic use of New xriticism, as opposed to Marxist or sociological criticism; the ominance of Niebuhrian neo-orthodox theology, in contrast to xcial-gospel theology; and the emergence of American Studies, articularly the national character approach to cultural analysis. $s$ these consensus intellectual constructs became dominant in re 1950s, American liberalism became quieter, more satisfied ith the system than it had been in the 1930s.

Interestingly, Kazan's directing career after On the Waterfront :veals a similar shift: before On the Waterfront his films are generally tore concerned with political and social conflict, whereas the films 'terwards - with the exception of Face in the Crowd (1957) - tend , be more overtly psychological. Kazan himself seems self-conious of this shift. When an interviewer suggested that he combined re social consciousness of Arthur Miller with the tragic sensibility ' Tennessee Williams, Kazan corrected him: "I'm not a combinaon of Miller and Williarns. I think I started more like Miller and zcame more like Williams" (Giment, 179). This shift from social rotest to tragic acceptance was reflected in his shifting approach 'ward characterization. In directing Williams' Baby Doll two zars after On the Waterfront, Kazan recalls that for the first time directing,

I tried to like everybody, to find everybody sympathetic and amusing ... Also, I tried to cool my loyalties. Up to now I'd always said: I'm for this side, I'm against that side. I'm against the gangsters on the waterfront. I'm for Marlon Brands's character... In this one I tried to deal with an equal balance of relationships. (Ciment, 76) 
The inner-directed man was becoming other-directed - the conflict view of society was being taken over by the consensus view, both for Mazan and the culture.

Thus it seems to me that On the Waterfront is closely related to American society in the early 1950s in the way it dramatizes certain tensions in American liberalism during that time of crisis. Though I have by no means given a thorough analysis of the film's aesthetic merits, I hope to have established that a full understanding of the film is impossible without taking Kazan's political dilemma in the early 1950s into account, just as I hope to have made it clear this film may help us understand what Raymond Williams has called the "structure of feeling" of the early 1950s. It seems no surprise to me that the film was showered with Academy Awards in 1955: the film industry was merely welcoming another Prodigal Son back into the home of true Americanism.

\section{POSTSCRIPT}

While Kazan worked out his dilemmas as a liberal in the narrative of On the Waterfront, life went on. Schulberg, perhaps dissatisfied with the film's ending, wrote a novel version (Waterfront, 1955) which concludes with Terry's death at the hands of the mob after his testimony. Further, Ken Hey tells us that Michael Clemente, the model for Johnny Friendly, was indicted in 1979 for attempting "to corruptly control and influence the waterfront industry in the Port of New York." Apparently, Johnny Friendly's final threat in the film - "I'll be back" - shows us that sometimes life imitates art.

\section{NOTES}

1 "Elia Kazan: A Structural Analysis," Cinema (Los Angeles) 7:3 (Winter, 1972-73), 26.

2 On American intellectuals in the 1930s, see Richard Pells, Radical Visions and American Dreams (New York: Harper, 1973). On the ideological consensus in America after 1945 see Geoffrey Hodgson, America in Our Time (New York: Doubleday, 1976), esp. chs. 1-4.

3 Michel Ciment, interviewer, Kazan on Kazan (New York: Viking, 1974), p. 12. Hereafter cited in the text in the form: (Ciment, page!.

4 The dilemmas of the ACLU, ADA, and ACCF are described in Mary McAuliffe, Crisis on the Left (Amherst: Univ. of Mass. Press, 1978). A briefer treatment of the three organizations is in Victor Navasky's Naming Names (New York: Viking, 1980), pp.45-58. Hook's comment is found there on p. 55. Hereafter: (Navasky, page). 
5 The executive sessions were closed to the press, and the testimonies during such sessions were usually not published. Kazan's was not, though his second testimony is published in full in Eric Bentley, ed., Thirty Years of Treason (New York: Viking, 1971), pp. 482-95. Hereafter: (Bentley, page). On Kazan's first testimony, see Roger Tailleur, "Elia Kazan and the House Un-American Activities Committee," trans. Alvah Bessie, Film Comment, 4:1 (1966), 68-78.

6 Walter Goodman, The Committee (New York: Farrar, 1968), p. 300. On HUAC and Hollywood, see also Robert Sklar, Movie-Made America (New York: Random, 1975), pp. 256-68.

7 Kazan and Miller, who had been good friends and associates, broke after Kazan's testimony, after which Miller wrote The Crucible. In that play a character says, "I speak my own sins. I cannot judge another." Practicing what he preached, Miller discussed his political views in his 1956 HUAC testimony but refused to name names. While no exact figures can be compiled Navasky (p. xii) estimates that of those from the entertainment industry who actually testified before HUAC, about one-third named names, despite the culture's taboo against informing.

8 New York Times, April 12, 1952, p. 7.

9 Interview with Paul Vanderwood, Oct. 6, 1976, in San Diego, CA, quoted in Vanderwood's "An American Cold Warrior: Viva Zapata," in John O'Connor and Martin Jackson, eds., American History/American Film (New York: Ungar, 1979), pp. 189-90.

10 Ciment, p. 110.

11 Johnson won a Pulitzer Prize for the series, then published the articles as a book, Crime on the Labor Front (New York: McGraw-Hill, 1950). Although Schulberg's contribution to the film should not be minimized, Kazan not only worked very closely with him on the screenplay - a somewhat unusual situation in the Hollywood studio years - but he also directed the film, supervised the editing, and retained "final cut" (the right to determine the exact final version of the film, usually held by the producer). Commenting on his working relationship with Kazan, Schulberg told an interviewer that the screenplay "was truly a labor of love, and the give-and-take I enjoyed in the preparation of the script was totally unlike anything I had ever known in my Hollywood screenwriting days." It should be added that Schulberg, well known as author of What Makes Sammy Run? and other novels, volunteered to testify before HUAC and named names. Thus, much of what I argue about Kazan's situation as a representative liberal of the McCarthy Era could also be applied to Schulberg. Navasky, pp. 239-46, shows that Schulberg defends his testimony strongly even today.

I2 Cobb, who knew Kazan in the Group Theater in the 1930s and who played Willie Loman in the first production of Death \& a Salesman, named names reluctantly before HUAC in 1953 after avoiding the committee two years. Broke, his wife institutionalized for alcoholism, alone with two small children, Cobb felt forced to testify. Apolitical today, he does not defend his informing like Schulberg and Kazan. As he told Navasky (p. 273), 'If I had not been in need, I'd never have co-operated."

13 On the importance of political commitment in art see Warren Susman, "The Thirties," in Stanley Coben and Lorman Ratner, eds., The Development of an American Culture (Englewood Cliffs, N.J.: Prentice-Hall, 1970), pp. 179-218, and Pells, 151-80 and 252-63. Harold Cluman provides a good view of how politics infused art in the Group Theater in The Fervent Years (New York: Innopf, 1945), while the British Film Institute Dossier No. 11, Coming to Terms with Hollywood, ed. Jim Cook and Alan Lovell (London: BFI, 1981), concentrates on how some 1930s leftists, including Kazan, tried to work their commitment into their HollywoodfilmsafterWWII. 
14 For information on the script development, see Ken Hey's excellent essay on the film: "Ambivalence as a Theme in On the Waterfront(1954), "American Quarterly, 31 (Winter, 1979), esp. 674-81. Hey's article is also particularly strong on the contributions of other collaborators, like cameraman Boris Kaufman and composer Leonard Bernstein.

15 "The Final Sequence of On the Waterfront," Sight and Sound, 24 (Jan.-March, 1955), 128.

16 Peter Biskin, "The Politics of Power in On the Waterfront," Film Quarterly, 29 (Fall, 1975), 28.

17 In his Times statement Kazan wrote: "I was held back from testifying, primarily, by concern for the reputations and employment of people who may, like myself, have left the party many years ago."

18 See Navasky, p. 210.

19 Navasky, p. 221.

20 Hodgson, pp. $75 \mathrm{ff}$.

21 On Viva Zapata, see Bentley, p. 494, and Vanderwood's essay (note 9). 